\title{
A Slovene-English Contrastive Analysis of One
}

\begin{abstract}
Avtorica razpravlja o različnih načinih prevajanja angleške besede one; rezultati naj bi bili v pomoč prevajalcem pri iskanju ustreznega slovenskega prevedka te besede. Na osnovi kontrastivne analize treh izvirnih besedil (dveh angleških in enega slovenskega) in petih prevodov (štirih v slovenščino in enega $v$ angleščino) predlaga nekaj možnih prevodnih ustreznic angleškega one.

The article attempts to determine whether there exist any regular equivalents in Slovene corresponding to English one, which could help translators from or into English in their work. On the basis of an analysis of three original texts (two English and one Slovene) and five translations (four into Slovene and one into English), several translational equivalents to various functions of one are proposed.
\end{abstract}

\section{The Aim}

The main aim of the present study is to determine whether there exist any regular patterns in the Slovene language which correspond to English one in those functions which do not have a one-to-one equivalent in Slovene. ${ }^{1}$ The results might be of some help to translators, enabling them to find appropriate equivalents to this English word more easily.

\section{Material and Methods of Work}

As the material for analysis the following books were used:

1. Cankar, Ivan. 1985. Dela III. Vol. 2, Hlapec Jernej in njegova pravica. Ljubljana: Cankarjeva založba.

2. Cankar, Ivan. 1968. The Bailiff Yerney And His Rights. Translated by H. C. Sewell Grant and S. Yeras. Ljubljana: Državna založba Slovenije.

3. Carroll, Lewis. <1950>. Alice's Adventures in Wonderland. New York: Random House Inc.

4. Carroll, Lewis. <1950>. Through the Looking-Glass. New York: Random House Inc.

5. Carroll, Lewis. 1951. Alica v deveti deželi. Translated by Bogo Pregelj. Ljubljana: Mladinska knjiga.

6. Carroll, Lewis. 1983. Alica v čudežni deželi. Translated by Gitica Jakopin. Ljubljana: Mladinska knjiga.

7. Carroll, Lewis. 1990. Aličine dogodivščine v čudežni deželi. Translated by Gitica Jakopin. Ljubljana: Mladinska knjiga.

\footnotetext{
${ }^{1}$ The paper summarizes a longer written work presented by the author during a two-year postgraduate course on contrastive analysis. I would like to thank Dr. Margaret Davis for reading and commenting upon the draft as well as the final version of this article.
} 
8. Carroll, Lewis. 1990. V ogledalu. Translated by Gitica Jakopin. Ljubljana: Mladinska knjiga.

All the examples containing the word one in Alice's Adventures in Wonderland and Through the Looking-Glass were compared with their Slovene translation equivalents found in Gitica Jakopin's and Bogo Pregeljs translations quoted above.

The aim of analyzing Cankar's Hlapec Jernej in njegova pravica was to find out when the translators decided to use the word one in English translation and to which source language term it corresponded. Therefore all the sentences containing one in the translation The Bailiff Yerney and His Rights were selected and then the equivalent source-language terms and phrases were analyzed. Since relatively few Slovene literary works have been translated into English by native English translators, only one text was chosen for this purpose. The reader should also bear in mind that this paper is mainly concerned with identifying the appropriate equivalents of one in Slovene and not vice-versa. I am aware of the fact that a more thorough analysis of Slovene texts translated into English should be made in order to offer more definite solutions.

For the determination of the different functions of one the following linguistic works and grammars were consulted: Cohesion in English by M. A. K. Halliday and R. Hasan, ${ }^{2}$ O. Jespersen Essentials of English Grammar ${ }^{3}$ and $A$ Modern English Grammar on Historical Principles, ${ }^{4} A$ Grammar of Contemporary English ${ }^{5}$ and $A$ Comprehensive Grammar of the English Language 6 by R. Quirk et al., Blaganje and Konte Modern English Grammar, ${ }^{7}$ and Collins Cobuild English Grammar. ${ }^{8}$ For comparison with the Slovene system Slovenska slovnica ${ }^{9}$ by Jože Toporišič was used.

\section{Functions of One}

The first three functions of one do not seem to be problematic, since all grammars consulted include these categories:

\footnotetext{
${ }^{2}$ M. A. K. Halliday and R. Hasan, Cohesion in English (London, Colchester, Beccles: Longman Group, 1976) .

${ }^{3}$ Otto Jespersen, Essentials of English Grammar (London: George Allen \& Unwin, 1933).

${ }^{4}$ Otto Jespersen, A Modern English Grammar on Historical Principles, Part II, VII - Syntax (London, Copenhagen: George Allen \& Unwin, 1909-1949). Jespersen's works were chosen as representatives of traditional grammars.

${ }^{5}$ R. Quirk et al., A Grammar of Contemporary English (Harlow: Longman Group, 1972).

${ }^{6}$ R. Quirk et al., A Comprehensive Grammar of the English Language (London, New York: Longman Group, 1985).

${ }^{7}$ D. Blaganje and I. Konte, Modern English Grammar (Ljubljana: Državna založba Slovenije, 1987). This grammar is based to a large extent on Quirk et al., A Grammar of Contemporary English (Harlow: Longman Group, 1972) but as a whole prepared for Slovene students and used at the University of Ljubljana as one of the basic course teaching materials.

${ }^{8}$ J. Sinclair, ed., Collins Cobuild English Grammar (London, Glasgow: William Collins Sons \& Co., 1990).

${ }^{9}$ Jože Toporišič, Slovenska slovnica, 2nd ed. (Maribor: Založba Obzorja 1984).
} 


\section{The cardinal numeral one $e^{10}$}

As such it is used with animate and inanimate singular countable nouns. It is considered to be a stressed variant of the indefinite article $a(n)$. It might be used in a determiner or in nominal functions:

$$
\text { one apple one of the apples }
$$
other. ${ }^{11}$

Numerical one also occurs in the correlative construction (the) one - the

She was turning from one side to the other.

One went this way, the other that way. ${ }^{12}$

Halliday and Hasan also mention the example: $:^{13}$

Ten set out, but only one came back.

as an instance of the numerical use of one. Here one is a nominal phrase which consists of a cardinal numeral premodifying an ellipted headword and thus functions as the headword of an ellipted nominal phrase. It is a case of ellipsis, since the presupposed item, if it is to be made explicit, is added to the presupposing one: it does not replace it as in the case of substitution:

Ten men set out, but only one man came back.

And not:

*Ten men set out, but only man came back.

In this case one can never be used in the plural and it usually does not take modifiers.

\section{The personal pronoun or generic person one $e^{14}$}

The generic person one is always singular and occurs alone in a nominal phrase. It means 'people in general'. The generic person also has the genitive one's and the reflexive oneself.

One would think she was mad. ${ }^{15}$

${ }^{10}$ For more see Blaganje, Konte, Modern English Grammar, 106; Halliday, Hasan, Cohesion in English, 98-99; Jespersen, Essentials of English Grammar, 197; Jespersen, A Modern English Grammar on Historical Principles 7:580-584; Quirk et al., A Grammar of Contemporary English, 221; Quirk et al., A Comprehensive Grammar of the English Language, 386; Sinclair, Collins Cobuild English Grammar, 115.

${ }^{11}$ See Quirk et al., A Grammar of Contemporary English, 221; Quirk et al., A Comprehensive Grammar of the English Language, 782-784; Sinclair, Collins Cobuild English Grammar, 42.

12 The examples are taken from Quirk et al., A Grammar of Contemporary English, 221.

${ }^{13}$ Halliday, Hasan, Cohesion in English, 98-99.

${ }^{14}$ See Blaganje, Konte, Modern English Grammar, 74; Halliday, Hasan, Cohesion in English, 98; Jespersen, Essentials of English Grammar, 150; Jespersen, A Modern English Grammar on Historical Principles, 7:156-158; Quirk et al., A Grammar of Contemporary English, 222; Quirk et al., A Comprehensive Grammar of English Language, 387-388; Sinclair, Collins Cobuild English Grammar, 31-32.

15 The example is taken from Jespersen, Essentials of English Grammar, 150. 


\section{One as a component of indefinite pronouns (any one, someone, no one,} every one $)^{16}$

Halliday and $\operatorname{Hasan}^{17}$ consider this one as a case of the "pro-noun" one, referring to definite human nouns only.

No one can cook like you.

\section{Nominal substitute one}

According to Halliday and Hasan ${ }^{18}$ the nominal substitute one always functions as the headword of a nominal group, and can substitute only for an item which is itself the headword of a nominal group. The noun that is presupposed is always a countable noun; there is no substitute for mass nouns:

These biscuits are stale. - Get some fresh ones.

This bread's stale. - Get some fresh. ${ }^{19}$

In the typical instance, the substitute "carries over" only the headword itself; it does not carry over any possible modifying elements, in fact, some modifying elements are always repudiated. However, in place of the original modifying elements the substitute regularly brings with it its own defining modifier.

We have no coal fires; only wood ones. ${ }^{20}$

"Coal" is repudiated and one is accompanied by the premodifying element "wood," which functions as defining in that particular context.

The substitute is thus a carrier of some information which differentiates the instance in which it occurs from the other instance to which it relates by cohesion. That means that the substitute one involves some redefinition of the "thing" that is represented by the headword and the repudiation of some information expressed by the headword to which it relates. There is always some point of contrast: the meaning of the nominal group containing the substitute is never exactly identical with that of the nominal group that is presupposed. Therefore one is always modified, and it has singular and plural forms.

I would like an apple. Take this green one.

I would like some apples. Don't take the rotten ones.

Halliday and Hasan distinguish between the nominal substitute one and the indefinite article one, ${ }^{21}$ which is the form taken by the indefinite article when it functions as the headword of an elliptical nominal group. It has the plural some and

${ }^{16}$ See Blaganje, Konte, Modern English Grammar, 91-102; Jespersen, Essentials of English Grammar, 82; Jespersen, A Modern English Grammar on Historical Principles, 2:443-446; Quirk et al., A Grammar of Contemporary English, 222-225; Quirk et al., A Comprehensive Grammar of the English Language 390-392; Sinclair, Collins Cobuild English Grammar, 35-38.

${ }^{17}$ Halliday, Hasan, Cohesion in English, 102-104.

${ }^{18}$ Halliday, Hasan, Cohesion in English, 91-98.

19 Ibid., 92.

${ }^{20}$ Ibid., 93-94.

${ }^{21}$ See Halliday, Hasan, Cohesion in English, 100-102. 
the negative and interrogative any. It functions as the headword of a nominal group without a modifier.

Are there any lions in those hills? Yes, I saw one on the way over. ${ }^{22}$

The instances when one is retained in a negative environment are also those where $a$ would be retained in the filled out equivalent, i.e., where the meaning is specifically singular:

"I vote the young lady tells us a story."

"I'm afraid I don't know one," said Alice. ${ }^{23}$

Quirk et al., on the other hand, classify two uses of the pro-form one. ${ }^{24}$ According to their Grammar of Contemporary English and A Comprehensive Grammar of the English Language:

1. One can substitute for an indefinite nominal phrase, and has the plural form some:

Can you give me a few nails? I need one.

I'll get you some soon. ${ }^{25}$

They point out that the above example could be interpreted either as a substitute or as elliptical for "one nail," in which case one would be the cardinal numeral. In speech, however, there is no ambiguity, since the numeral is differentiated from the pro-form one in that the former carries a stress.

That means that according to this classification the above-described function of one could be identified as a substitute or a numeral, but never as an article.

2. One can also substitute for the headword of a nominal phrase, and has the plural form ones:

Have you got any knives? I need a sharp one.

One as pro-form for the headword of a nominal phrase must have an overt determiner or modifier. ${ }^{26}$

The second use is clearly the case of Hasan and Halliday's nominal substitution.

Jespersen talks about the prop-word one, which seems to be just another name for a nominal substitute. It has "the important function of serving as primary (headword) on which to hang a secondary (modifier) which, for some reason or other, cannot very well or conveniently stand alone as a primary." ${ }^{27}$ It occurs:

22 Ibid., 101

23 Ibid.

${ }^{24}$ See Quirk et al., A Grammar of Contemporary English 679-680; Quirk et al., A Comprehensive Grammar of the English Language 869-870.

${ }^{25}$ Quirk et al., A Grammar of Contemporary English, 679; Quirk et al., A Comprehensive Grammar of the English Language, 869.

${ }^{26}$ A similar, though much shorter, definition could also be found in Sinclair, Collins Cobuild English Grammar, 42. See also Blaganje, Konte, Modern English Grammar, 175-177, where the nominal substitute one is called "the pro-word one."

27 Jespersen, Essentials of English Grammar, 83-85. See also Jespersen, A Modern English Grammar on Historical Principles, 2:254-271; 2:317-318. 
- after $a$ : such a one

- with the definite article:

This grey horse is stronger than the black one.

- after a numeral and an adjective:

German teachers had rather manage a dozen German boys than one English one.

- when we have the plural ones:

Don't let us make imaginary evils, when we have so many real ones to encounter. ${ }^{28}$

When one stands alone without modifiers, Jespersen defines it as a pronoun of indefinite unity. ${ }^{29}$ Under this title he enumerates many different usages of one, including Halliday and Hasan's one functioning as an article or Quirk's one functioning as a substitute for the indefinite nominal phrase:

She was now a free agent - if she had not formerly been one. ${ }^{30}$

What should we call then the function of one that is used in a sentence without modifiers and clearly refers back to a previously mentioned nominal phrase? An article or a pro-form, or a numeral with ellipted headword?

A pro-form can be distinguished from a numeral in speech: the numeral is stressed while the pro-form is not. That means that the function of one could be defined according to each specific speech situation.

Since the definite and the indefinite articles can never be used in nominal function, but only as modifiers, and one, on the other hand, always functions as the headword of a nominal group, it seems wise not to share Halliday and Hasan's decision to define one in such a use as an article. Therefore Quirk's classification has been used in this paper.

To sum up, according to our classification:

1. One can substitute for an indefinite nominal phrase, and has a plural form some:

Can you give me a few nails? I need one.

I'll get you some.

2. One can also substitute for the headword of a nominal phrase, and has a plural form ones:

Have you got any knives? I need a sharp one.

I need some sharp ones.

\section{One functioning as a pro-noun ${ }^{31}$}

It is restricted to human referents only and is not a substitute form. It has the meaning of 'person' and its plural form ones means 'people'.

Who does he need? The one he needs is his lawyer.

\footnotetext{
${ }^{28}$ All the examples are taken from Jespersen, Essentials of English Grammar, 83.

${ }^{29}$ Jespersen, Essentials of English Grammar, 174.

30 Ibid.

${ }^{31}$ See Halliday, Hasan, Cohesion in English, 102-104.
} 


\section{One as a pronoun of indefinite unity ${ }^{32}$}

For all the other functions and meanings of one, it seems wise to take Jespersen's above-mentioned term. Under this title the following examples would be listed: He mentioned as his source an English lady, one Miss Arundel. ('a certain')

One day you are sure to repent of this. ('some')

Rain or sunshine, that is all one to me. ('one and the same') $)^{33}$

\section{Examples}

As already mentioned, the corpus consists of all the sentences containing the word one in two original English literary texts and an English translation of a Slovene literary text, i.e., L. Carroll's Alice's Adventures in Wonderland and Through the Looking-Glass and I. Cankar's Hlapec Jernej in njegova pravica respectively. The examples featuring in this study are among the most typical representatives of the various functions explained above. The conclusions, however, are based on an analysis of all the examples.

\section{One as a Cardinal Numeral}

A 1 ice's Adventures in Wonderland

Unless explicitly mentioned otherwise, the translations of Alice's Adventures in Wonderland are listed in the following order:

1. Lewis Carroll, Alica v čudežni deželi, translated by Gitica Jakopin. Ljubljana: Mladinska knjiga, 1983.

2. Lewis Carroll, Aličine dogodivščine v čudežni deželi, translated by Gitica Jakopin. Ljubljana: Mladinska knjiga, 1990.

3. Lewis Carroll, Alica v deveti deželi, translated by Bogo Pregelj. Ljubljana: Mladinska knjiga, 1951.

1. Alice's first idea was that this might belong to one of the doors of the hall ... (21)

2. And when Alice had been all the way way down one side and up the other ... (20)
Alica je najprej pomislila na to, da mora biti ključ za katera od vrat ... (9)

Alica je najprej pomislila, da bo morda odprl katera od vrat v dvorani ...(16)

Alica je najprej pomislila, da bi to utegnil biti ključ $\mathrm{k}$ enim od vrat, ki so peljala iz dvorane. (12)

Alica je obšla najprej eno stran, potem drugo ... (9)

Alica je obšla najprej eno, potem drugo stran ... (15)

Ko je Alica zaman poskušala odpreti najprej na eni strani vrata za vrati, nato pa še na drugi strani ... (12)

Of all the functions of one the numerical one is the most common, i.e., 65 English sentences containing numerical one were found in the material analyzed.

\footnotetext{
${ }^{32}$ See Jespersen, Essentials of English Grammar, 174.

${ }^{33}$ All the examples are taken from ibidem.
} 
The most common translation equivalent is the Slovene cardinal numeral en, ena, eno or eden; in fact, there were 92 examples of Slovene sentences containing a cardinal numeral found in the translations analyzed, one of them being Bogo Pregeljs translation in example 1. Also the first element in the correlative construction (the) one - the other is usually translated by a cardinal numeral (example 2).

Three times one was translated by the pronoun kateri - $a$-o ("poljubnostni pridevniški zaimek"). ${ }^{34}$

There is a slight difference in meaning between "one of the doors of the hall" and "katera od vrat v dvorani," the latter expressing that the key might open one or more doors of the hall, while in the original one indicates more explicitly that the key most probably opens only one of the doors. However, the translation of a numerical one indicating a part or a fraction of the whole by the pronoun kateri ("poljubnostni zaimek") is surely a "trouvaille."

3. The Mock Turtle sighed deeply, and drew the back of one flapper across his eyes. (195)
Ponarejena želva je globoko vzdihnila in si s hrbtom desne nožne plavutke potegnila čez oči. (82)

Ponarejena želva je globoko vzdihnila in si s hrbtom plavutke obrisala oči. (111)

Ponarejena želva je globoko vzdihnila in si otrla s hrbtom šape oči. (98)

Often there is no target language equivalent to be found in Slovene translations (in 28 cases); the omissions are especially frequent when one premodifies a noun indicating a part of a human or animal body.

4. After a while she remembered that she still held the pieces of mushroom in her hands, and she set to work very carefully, nibbling first at one and then at the other ... (62)
Čez čas se je pa le domislila, da ima vendar še $v$ rokah dva koščka, zato se ju je lotila na moč previdno: odgriznila je najprej malo tu, potem malo tam ... (44)

(...) Odgriznila je najprej malo tukaj, potem malo tam ... (61)

(...) In jih je začela previdno pokušati, zdaj tega, zdaj onega. (52)

In all the other cases the translators paraphrased the original, exchanging the numerical one for translational equivalents ranging from ordinal numerals to adverbs of place and demonstrative pronouns.

$$
\text { H lapec Jernej in n jegova pravica }
$$

5. I have not buried one master only, Nisem pokopal enega gopodarja, dvoje to-day, but two of them. (8) sem jih pokopal! (168)

\footnotetext{
${ }^{34}$ See Toporišič, Slovenska slovnica, 278.
} 
6. So close one to another that no free space is left between them. (57)

7. And dragged from one door to another ... (76)

If we compare the above findings with the translation of Cankar's Hlapec Jernej in njegova pravica, we can see that the numerical one usually corresponds to Slovene en, eden (in 6 cases). In all the other cases (also 6 cases) the correlative pair one - another is used to translate correlative structures in Slovene (e.g., "od duri do duri," "druga tik druge," "kazalec na kazalec").

\section{One as a Personal Pronoun or Generic Person}

\section{Alice's Adventures in Wonderland}

1. It's enough to drive one crazy! (65)

Človek bi ponorel. (46)

Človek bi znorel od tega! (64)

Pri njih še znorim! (54)
2. It's one of the most serious things that can possibly happen to one in a battle - to get one's head cut off. (193) (236)

The most usual way of translating the generic person one into Slovene is by using the Slovene generic person človek (in four cases); however, the impersonal form of the verb with the particle se is quite common in the translations as well (example 3). Three times instead of generic one, the personal pronoun $t i$ with generic meaning is used in Slovene (example 2).

$$
\text { H lapec Jernej in n jegova pravica }
$$

4. There are so many priests that one Duhovnikov je toliko, da bi držal člomight as well keep one's hat in one's vek klobuk kar v roki. (200) hand. (57)

In the translation of Hlapec Jernej in njegova pravica 4 occurrences of the generic one were found. One in this function was usually rendered by the generic človek in the original (three times). Once it was omitted.

\section{One as a Part of Indefinite Pronouns}

Alice's Adventures in Wonderland

1. She was rather glad there was no Tokrat pa je bila Alica kar vesela, da je one listening, this time. (18)

nihče ne posluša ... (8) 
Pravzaprav je bila vesela, da je tokrat nihče ne sliši, ker ji ta beseda sploh ni prav zvenela. (14)

Bila je kar vesela, da ni bilo nikogar blizu ... (11)

2. She was ready to ask help of any one ... (27)
Alica je bila že tako obupana, da bi bila kogarkoli prosila za pomoč ... (15)

Alica je bila že tako obupana, da bi kogarkoli poprosila za pomoč ... (22)

Alica je bila tako obupana, da bi prosila kogar koli, naj ji pomaga. (19)

No one ( 3 cases) is always translated by the negative pronouns nihče and nobeden; any one ( 5 cases) by the pronouns $k d o$ and kdorkoli ("poljubnostni zaimek") or it is paraphrased. Someone (3 cases) is translated by the pronouns kdo or nekdo ("nedoločni zaimek") or paraphrased, and every one twice by the pronoun vsak $-a$ - $o$ ("posamostaljeni pridevniški zaimek"). ${ }^{35}$

The translation of Hlapec Jernej in njegova pravica provides only one example of the indefinite pronoun including one, where no one corresponds to the negative pronoun nobeden.

\section{One as a Nominal Substitute}

One as a nominal substitute is a cohesive device. The reader should bear in mind that although cohesion is found within a sentence as well as between sentences, only cohesion across sentence boundaries is usually considered cohesion proper. The following examples mainly fall into the class of internal cohesion (i.e., within a sentence); but nevertheless usefully indicate the available traslational equivalents.

\section{a) One as a Substitute for the Head of a Nominal Phrase}

\section{Alice's Adventures in Wonderland}

1. The next thing was to eat the comfits: this caused some noise and confusion, as the large birds complained that they could not taste theirs, and the small ones choked and had to be patted on the back. (38-39)
To pa ni šlo brez hrupa in zmede, kajti veliki ptiči so tožili, da to sploh nima nobenega okusa, manjšim so pa bonboni obtičali $\mathrm{v}$ goltancu. (24)

To je izzvalo precej hrupa in zmešnjave, ker so se veliki ptiči pritoževali, da sploh niso prišli do okusa, ptički so se hoteli pa zadaviti, tako, da jih je bilo treba potolči po hrbtu. (34)

To seveda ni šlo brez hrupa in nereda. Velike ptice so se namreč pritoževale, da so svoje sladkorčke komaj okusile, malim pa so se zataknili $\mathrm{v}$ grlu in so jih morali tolči po hrbtu. (30)

${ }^{35}$ See Toporišič, Slovenska slovnica, 248; 271-278. 
Through the Looking-G1as s

2. Of all the strange things that Alice saw in her journey Through the Looking-Glass, this was the one that she always remembered most clearly. (244)
Od vseh nenavadnih dogodivščin, kar jih je Alica doživela na svojem popotovanju za ogledalom, ji je ta ostala $v$ spominu najbolj čisto. (270)

One as a substitute for the head of a nominal phrase is usually translated (twelve cases out of 22) by an adjective or a substantivized adjective, i.e., the adjective that replaces a nominal phrase consisting of a nominal headword premodified by an adjective. The adjective in Slovene should be used in its classifying form ("določna oblika"). ${ }^{36}$

Three times an adverb is used as a translation equivalent, and twice a new noun was introduced (e.g., "ptički" for "small ones" meaning 'small birds'). Once a reference item (a demonstrative pronoun) is used to form a cohesive link (example 2 ). In all the other examples (4 cases) the translators interpreted the meaning.

$$
\text { H lapec Jernej in njegova pravica }
$$

3. I think my cause is one which will To je pravda po božji volji! (190) find favour in God's sight ... (41)

4. Thank you for your words, though Pozdravljene tudi vaše besede, kakor so they were harsh ones. (92)

bile neprijazne! (224)

In the translation of Hlapec Jernej in njegova pravica, one as a substitute for the head of a nominal phrase (4 examples were found) twice corresponds to an adjective. The adjective in this function is always used in the classifying form. In the other two cases the translators chose to interpret the original (e.g., example 3).

\section{b) One as a Substitute for an Indefinite Nominal Phrase}

\section{A 1 ice's Adventures in Wonderland}

1. When I used to read fairy tales, I fancied that kind of thing never happened and now here I am in the middle of one! (44-45)
Kadar sem brala pravljice, sem zmeraj mislila, da takih reči $\mathrm{v}$ resničnem življenju ni, zdaj sem pa sama sredi pravljice! (30)

Ko sem prej brala pravljice, sem mislila, da se takšne reči $\mathrm{v}$ resnici nikoli ne zgodijo, zdaj sem pa sama sredi take dogodivščine. (41-42)

Kadar sem svoj čas brala pravljice, sem si domišljala, da se kaj takega $\mathrm{v}$ resnici ne dogaja, sedaj sem sama padla prav na sredo pravljice. (38)

\footnotetext{
${ }^{36}$ See Toporišič, Slovenska slovnica, 264.
} 
2. There ought to be a book written about me, that there ought! And when I grow up, I'll write one ... (45)
Pravzaprav bi moral kdo napisati knjigo o meni, prav zares! Ko bom odrasla, jo bom jaz napisala; (toda odrasla sem že zdaj!) (30)

Saj bi kdo moral napisati knjigo o meni, pa še kakšno! Ko bom odrasla, jo bom sama napisala. (42)

Še o meni bi morali pisati knjigo, prav zaresno knjigo! Ko bom velika, jo bom sama napisala. (38)

Through the Looking-Glas s

3. "Now then! Show your ticket, child!" "No, bo kaj? Pokaži karto, otrok!" (...) (...)

"I'm afraid I haven't got one," Alice said "Oprostite, ampak jaz nimam karte," je preplašeno povedala Alica. (183) "Tam, od koder sem prišla jaz, ni bilo nobene blagajne." (...)

"Tam, od koder je prišla ona, nimajo prostora za blagajne." (...) "Nič se ne izgovarjaj," je rekel sprevodnik, "bi jo bila kupila pa pri strojevodji!" (183-184)

One as a substitute for an indefinite nominal phrase is in 15 cases out of 42 translated by a reference item, usually a pronoun, thus evading repetition but nevertheless providing a cohesive link (example 2).

Very often (in fact, in 15 cases) the substitute one corresponds to the repetition of the noun the substitute in the original refers to. Once a translator introduced a near-synonym (example 1).

4. Alice did not at all like the tone of this remark, and thought it would be as well to introduce some other subject of conversation. While she was trying to fix on one, the cook took the cauldron of soup off the fire ... (66)
Ton te njene pripombe ni bil Alici niti najmanj všeč, in pomislila je, da bi bilo morda pametneje, če začne o čem drugem. Ko je že premišljevala, o čem, je kuharica kotel $\mathrm{z}$ juho iznenada vzela $\mathrm{z}$ ognja ... (48)

Alici ni bil preveč pogodu ton te pripombe in pomislila je, da bi bilo morda pametno, če pogovor spelje na kaj drugega. Ko je že premišljevala, kaj bi to lahko bilo, je kuharica vzela $\mathrm{z}$ ognja kotel z juho ... (66)

Alici ni bilo nikakor všeč, kako je bila ta opazka poudarjena, zato je menila, da bi bilo najbolje, če bi sprožila kak- 
šen drugačen pogovor. Še preden se je domislila, kaj bi, je vzela kuharica $\mathrm{z}$ ognja kotel z juho ... (57)

The translators often chose to paraphrase (in 7 cases); the substitute one in example 4 is thus translated by clauses, twice elliptical and once with a clause containing a reference item - a demonstrative pronoun. By means of this interlingual level shift one is replaced by a dependent (sometimes elliptical) clause (in 4 cases).

The translation of Hlapec Jernej in njegova pravica offers no examples of one functioning as a substitute for an indefinite nominal phrase.

\section{One Functioning as a Pro-Noun}

Through the Looking-Glas s

1. I'm one that has spoken to a King... Jaz sem že govoril $\mathrm{z}$ nekim kraljem ... (210) (231)

2. Does the one - that wins - get the crown? (226)

In zmagovalec - potem dobi - krono? (249)

3. However, she didn't see why the Red

Alici pa vseeno ni šlo v glavo, zakaj naj Queen should be the only one to give orders ... (262) bi ukazovala samo črna kraljica ... (290)

H lapec Jernej in njegova pravica

4. Almost suffocated with laughter, the Oddahnil si je kmet od smeha, odkašljal farmer coughed, and pointing with his finger towards the musician: "Look at that one! It never entered his head to se je in pokazal s prstom na godca. Glej, temu ni prišlo na misel, da bi tožil ... (198) sue me." (54)

Five cases of the pro-noun one were found in English texts. In two cases the translators chose to paraphrase, which could not help us with our generalizations. However, there are some interesting solutions, which merit our attention. In the first example the Slovene equivalent of one functioning as a pro-noun is an explicitly expressed personal pronoun, which in the nominative case is usually omitted except when emphasis is required. ${ }^{37}$

"One that wins" becomes the agent noun "zmagovalec" in Slovene, thus losing the emphatic effect, which is also true of the last example, where a slightly more emphatic form would also be possible: e.g., “...zakaj naj bi bila samo črna kraljica tista, ki ukazuje."

In the translation of Hlapec Jernej in njegova pravica the pro-nominal one corresponds to an emphatically used demonstrative pronoun.

\footnotetext{
${ }^{37}$ See Toporišič, Slovenska slovnica, 242.
} 


\title{
VI. One as a Pronoun of Indefinite Unity
}

\author{
H lapec Jernej in n jegova pravica
}

1. May a good seed, which one day Naj pade seme vanjo, da bo klilo in zowill sprout and yield wholesome fruit ... relo nekoč! (184)

(34)

One as a pronoun of indefinite unity could only be found in the translation of Cankar's Hlapec Jernej in njegova pravica (in 5 cases). In all cases it is used as a translation equivalent for "nekoč." Four times "nekoč" is translated by "one day" and once by "one evening," which means that one was always used with the meaning 'some'.

\section{Conclusion}

It may be claimed, on the basis of the material analyzed, that the Slovene language does not have any word which would correspond to one in all its functions. However, some generalizations could be made according to each particular function of one.

In translations from English into Slovene, i.e., decoding, one functioning as a cardinal numeral or the first item in the correlative pair one-another, one-other is rendered, in most cases, by the Slovene cardinal numeral en - $a-o$, eden (e.g., "One, two, three, and away!" - "En, dva, tri, zdaj!"). Often the numeral is omitted in Slovene, especially when it premodifies a part of a human or animal body (e.g., "The Mock Turtle sighed deeply, and drew the back of one flapper across his eyes." - "Ponarejena želva je globoko vzdihnila in si s hrbtom plavutke obrisala oči."). The analysis of the existing translations of Alice's Adventures in Wonderland also showed that one could be translated by the so-called "poljubnostni vrstni pridevniški zaimek" (kateri $-a-o)^{38}$ (e.g., "(...) this might belong to one of the doors of the hall ..." - “(...) da mora biti ključ za katera od vrat ...”).

When translating from Slovene into English, i.e., encoding, the numerical one almost without exception corresponds to Slovene en, eden. Some Slovene correlative structures (e.g., "od duri do duri," "druga tik druge," "kazalec na kazalec") are translated by the correlative pair one - another to avoid repetition.

The numerical one thus does not seem to represent a problem when translating into or from English. However, it should be noted that the numerical one often pre-modifies parts of a human or animal body in English and is omitted in that function in Slovene and that the use of kateri $-a-o$ ("poljubnostni pridevniški zaimek") can replace the sometimes awkward equivalent en -a -o izmed.

The most usual Slovene translation equivalent of the generic person one is the corresponding generic person in Slovene - človek. (e.g., "It is enough to drive one crazy!" - "Clovek bi ponorel!") Another possible translation is the impersonal verb form with se (e.g., "Now one can breathe more easily." - "Tako se veliko laže diha."), or the use of the generic person $t i$ (e.g., "(...) to get one's head cut off." "(...) da ti kdo odseka glavo.") In the translation into English of Hlapec Jernej in njegova pravica, one corresponds to the generic človek in the original (e.g., "(..) da

${ }^{38}$ See Toporišič, Slovenska slovnica, 271-275. 
bi držal človek klobuk kar v roki.” - “(...) one might as well keep one’s hat in one's hand.").

It seems that the generic one, which is considered formal in English ${ }^{39}$ corresponds to the equally formal človek in Slovene.

One as a part of an indefinite pronoun is usually translated by the corresponding Slovene pronoun. Thus the most frequent translation equivalent of no one is the negative pronoun nihče or nobeden ${ }^{40}$ (e.g., “(..) there was no one listening, this time." - “(...) da je nihče ne posluša."), of any one: kdo or kdorkoli ("samostalniški poljubnostni zaimek") $)^{41}$ (e.g., "She was ready to ask help of any one ..." - "(...) da bi kogarkoli poprosila za pomoč..."), of someone: $k d o$ or nekdo ("samostalniški nedoločni zaimek") ${ }^{42}$ (e.g., "(...) and longing for someone to speak." - "In srčno si je želela, da bi kdo spregovoril."), and of every one: vsak - a -o ("posamostaljeni pridevniški zaimek") ${ }^{43}$ (e.g., "Silence, every one of you!" - "Da ste mi takoj tiho vse po vrsti!").

The translation of Hlapec Jernej in njegova pravica into English provides only one example of the indefinite pronoun including one, where nobeden is translated with no one. However, we could conclude that indefinite pronouns are not problematic for a translator from or into English; they basically correspond to the above mentioned Slovene pronouns.

In the majority of cases, one as a substitute for the head of a nominal phrase is translated into Slovene by an adjective (e.g., "The table was a large one." - "Miza je bila velika.") or by a substantivized adjective ("Do you know I always thought Unicorns were fabulous monsters, too? I never saw one alive before!" - "Veš, jaz pa sem vedno mislila, da ste samorogi nekakšne pošasti iz pravljic! Toda živega nisem videla še nobenega!"). The adjective in Slovene should be used in its classifying form ("določna oblika"). Sometimes a new noun may be introduced instead of a substitute (e.g., "(...) the large birds complained that they could not taste theirs, and the small ones choked ..." - “(...) ker so se veliki ptiči pritoževali, da sploh niso prišli do okusa, ptički so se hoteli pa zadaviti ...").

In the translation of Hlapec Jernej in njegova pravica four examples of one functioning as a substitute for the head of a nominal phrase were found. One in this function twice corresponded to an adjective (e.g., "Pozdravljene tudi vaše besede, kakor so bile neprijazne." - "Thank you for your words, though they were harsh ones."), and twice it was interpreted (e.g., "To je pravda po božji volji." - "I think my cause is one which will find favour in God's sight ...").

Therefore the advice given to translators by Blaganje-Konte ${ }^{44}$ that one functioning as a pro-word, i.e., as a substitute for the head of a nominal phrase, should be translated by substantivized Slovene adjectives is not always applicable. When decod-

\footnotetext{
${ }^{39}$ See for example Jespersen, Essentials of English Grammar, 151.

${ }^{40}$ See Toporišič, Slovenska slovnica, 272.

${ }^{41}$ See ibid., 272.

${ }^{42}$ See ibid., 272.

${ }^{43}$ See ibid., 248; 272.

${ }^{44}$ Blaganje, Konte, Modern English Grammar, 175 (note).
} 
ing, a translator should bear in mind that an adjective or a new noun could also be used as translation equivalents for the nominal substitute. On the other hand, when translating into English, the relative scarceness of one as a substitute for the head of a nominal phrase suggests that translators are often not aware of this English cohesive device and therefore do not use it.

One as a substitute for an indefinite nominal phrase is most commonly rendered into Slovene by a reference item, usually a pronoun (e.g., "There ought to be a book written about me, that there ought! And when I grow up, I'll write one ..." - "Saj bi kdo moral napisati knjigo o meni, pa še kakšno! Ko bom odrasla, jo bom sama napisala."). Equally frequent is the repetition of the noun to which the substitute refers in the original (e.g., "When I used to read fairy tales, I fancied that kind of thing never happened and now I am in the middle of one!" - "Kadar sem brala pravljice, sem zmeraj mislila, da takih reči $\mathrm{v}$ resničnem življenju ni, zdaj sem pa sama sredi pravljice!"). Sometimes a near-synonym is introduced (e.g., “(...) zdaj sem pa sama sredi take dogodivščine.").

Convincing evidence that one as a substitute is easily forgotten in translating from Slovene into English despite its considerable frequency in the latter is that the translation of Hlapec Jernej in njegova pravica does not use this cohesive device even once. The reason seems to be that Slovene does not offer any one-to-one correspondent to one as a nominal substitute. Translators, however, should be aware of the fact that the repetition of the same noun, the introduction of a near-synonym, and the over-use of reference items, such as pronouns, are not as frequent stylistic devices in English as they are in Slovene, and that nominal substitutes are often used to avoid these strategies.

One as a pro-noun could be translated into Slovene by an explicitly expressed personal pronoun (e.g., "I'm one that has spoken to a King ..." - "Jaz sem že govoril z nekim kraljem ..."). However, it seems that it is usually paraphrased (e.g., "Does the one - that wins - get the crown?" - "In zmagovalec - potem dobi krono?").

In translation of Hlapec Jernej in njegova pravica we found only one case of one functioning as a pro-noun, and it corresponded to an emphatically used demonstrative pronoun ("Glej, temu ni prišlo na misel, da bi me tožil ..." - "Look at that one! It never entered his mind to sue me.”). It seems that an explicitly expressed personal pronoun or emphatically used demonstrative pronoun referring to persons could skillfully be translated into English by one as a pro-noun, and that these two pronouns could also be used as Slovene equivalents for one in this function.

And finally, one as a pronoun of indefinite unity was found only in the translation of Hlapec Jernej in njegova pravica. It always had the meaning 'some' (e.g., "When, one day, I lay it down ..." - "Kadar pa odložim nekoč ..."). In Slovene it seems to correspond to the pronoun neki $-a-o$ ("nedoločni vrstni pridevniški zaimek"), ${ }^{45}$ which can sometimes be already implicit in some terms in Slovene, e.g., in "nekoč," which could be paraphrased by "nekega dne." As such it should not represent any serious problems to a translator to or from English.

To sum up, one as a numeral, generic person, indefinite pronoun, pro-noun and pronoun of indefinite unity does not seem to represent any considerable problem

\footnotetext{
${ }^{45}$ See Toporišič, Slovenska slovnica, 278.
} 
to a translator from or into Slovene, which could not be said for one as a nominal substitute, since traditionally proposed substantivised Slovene adjectives are not always applicable. Moreover, translators do not seem to be sufficiently aware of this cohesive device, therefore one hardly ever occurs in the translation from Slovene into English.

Prispelo decembra 1994, sprejeto decembra 1996

Received December 1994, accepted December 1996

\section{Slovensko-angleška kontrastivna analiza angleške besede one}

Avtorica razpravlja o različnih načinih prevajanja angleške besede one, še posebno $\mathrm{v}$ tistih primerih, kjer slovenščina nima podobnega enobesednega ustreznika. Tako analizira tri izvirna besedila (dve angleški in eno slovensko) in pet prevodov (štiri v slovenščino in enega $\mathrm{v}$ angleščino). Rezultati naj bi bili v pomoč prevajalcem, ki bi tako lažje našli primerne ustreznice angleškemu one.

Avtorica s pomočjo strokovne literature in različnih sodobnih slovnic najprej določi šest različnih funkcij angleškega one, in sicer one kot glavni števnik, one kot splošni osebni zaimek, one kot sestavni del nedoločnih zaimkov anyone, someone, no one in every one, one kot za-oblika, one kot za-imek in one kot zaimek nedoločnosti.

Čeprav slovenščina nima enobesednega ustreznika, ki bi lahko nadomeščal one $\mathrm{v}$ vseh funkcijah, lahko na osnovi analiziranih besedil znotraj posameznih funkcij pri prevajanju te besede kljub temu začrtamo določene smernice.

Pri dekodiranju, tj. prevajanju iz angleščine v slovenščino, se one kot glavni števnik ali kot prvi element $\mathrm{v}$ paru one-another, one-other $\mathrm{v}$ analiziranih besedilih večinoma prevaja s slovenskim glavnim števnikom en $-a-o$, eden. Opazimo pa lahko, da prevajalci števnik $\mathrm{v}$ slovenščini pogosto izpuščajo pred deli človeškega ali živalskega telesa. Pri enkodiranju, tj. prevajanju iz slovenščine $\mathrm{v}$ angleščino, sta prevajalca vedno uporabila števnik one kot prevedek za en, eden. Izjema so bile določene slovenske korelativne strukture (npr. »od duri do duri«), ki sta jih prevajalca prevedla $\mathrm{z}$ one-another in se tako izognila ponovitvi.

Kot slovenski prevedek splošnega osebnega zaimka one najpogosteje najdemo zaimenski samostalnik človek. $\mathrm{V}$ prevodih pa niso redke tudi prevodne enote $\mathrm{s}$ splošnim vršilcem dejanja in preneseno rabo 2. os. ednine. Pri enkodiranju splošni osebni zaimek one v izvirniku vedno ustreza zaimenskemu samostalniku človek.

One kot del nedoločnega zaimka se po navadi prevaja $\mathrm{z}$ ustreznim zaimkom v slovenščini. Tako se no one najpogosteje prevaja $\mathrm{z}$ nikalnim zaimkom nihče ali nobeden, any one s samostalniškim poljubnostnim zaimkom $k d o$ ali kdorkoli, someone $\mathrm{s}$ samostalniškim nedoločnim zaimkom $k d o$ ali nekdo ter every one s posamostaljenim pridevniškim zaimkom vsak $-a-o$. V prevodu iz slovenščine $\mathrm{v}$ angleščino najdemo en sam primer nedoločnega zaimka $\mathrm{z}$ one, ki ustreza zaimku nobeden $\mathrm{v}$ izvirniku. 
$\mathrm{V}$ večini primerov se one kot za-oblika, in sicer one kot nadomestek za jedro samostalniške fraze, prevaja $\mathrm{v}$ slovenščino $\mathrm{s}$ pridevnikom ali posamostaljenim pridevnikom, ki pa je vedno v določni obliki. Včasih prevajalci uvedejo nov samostalnik, kar kaže na to, da tradicionalnega napotka prevajalcem, naj se one v tej funkciji prevaja s posamostaljenim slovenskim pridevnikom, ni mogoče vedno upoštevati. Pri enkodiranju sta prevajalca uporabila one $\mathrm{v}$ tej funkciji le štirikrat, in sicer dvakrat kot prevedek za slovenski pridevnik, dvakrat pa je bil one del njune parafraze izvirnika.

One kot nadomestek za nedoločno samostalniško frazo se najpogosteje prevaja $\mathrm{s}$ slovenskimi zaimki, pogosti pa so tudi prevodi s ponovitvijo samostalnika, ki ga zamenjuje one v izvirniku. Včasih pa prevajalci uvedejo tudi delni sinonim oz. parafrazo. $\mathrm{V}$ prevodu slovenskega besedila $\mathrm{v}$ angleščino prevajalca nista uporabila one $\mathrm{v}$ tej funkciji niti enkrat; zdi se, da se prevajalci premalo zavedajo, kako ponovitev istega samostalnika, uvedba delnega sinonima in pretirana uporaba zaimkov niso tako pogosti stilistični prijemi $\mathrm{v}$ angleških besedilih kot $\mathrm{v}$ slovenskih in da $\mathrm{v}$ angleških besedilih $\mathrm{v}$ teh primerih pogosteje najdemo $\mathrm{v}$ tej funkciji besedo one.

One kot za-imek, tj. kadar pomeni 'oseba' oz. v množini 'ljudje', v slovenščini postane poudarjen osebni zaimek, pogosto pa ga prevajalci tudi parafrazirajo. $\mathrm{V}$ prevodu v angleščino one $\mathrm{v}$ tej funkciji ustreza poudarjenemu kazalnemu zaimku.

One kot zaimek nedoločnosti se pojavi le pri enkodiranju, in sicer vedno v pomenu 'neki -a -o'.

Tako one $\mathrm{v}$ funkciji glavnega števnika, splošnega osebnega zaimka, nedoločnega zaimka, za-imka in zaimka nedoločnosti prevajalcem iz slovenščine in vanjo ne povzroča resnejših težav, kar pa ne velja za one v funkciji za-oblike, saj pri dekodiranju kot prevedek ne moremo vedno uporabiti posamostaljenega pridevnika. Poleg tega se zdi, da se prevajalci pri prevajanju $\mathrm{v}$ slovenščino premalo zavedajo pogostnosti uporabe tega kohezivnega elementa $\mathrm{v}$ angleščini, saj one $\mathrm{v}$ tej funkciji $\mathrm{v}$ prevodih zasledimo precej redko.

\section{A Slovene-English Contrastive Analysis of One}

The author discusses various means of translating the English word one, particularly in those instances where Slovene does not have a one-word equivalent. Three original texts are treated (one English and two Slovene) and five translations (four into Slovene and one into English). The results are intended to help translators more easily find appropriate equivalents to English one.

With the aid of linguistic literature and various modern grammars, the author defines six distinct functions of English one: as a cardinal numeral, as a generic person, as a component of an indefinite pronoun (anyone, someone, no one, every one), as a nominal substitute, as a pro-noun, and as a pronoun of indefinite unity.

Although Slovene lacks a one-word equivalent in all these functions, one can on the basis of the textual analysis propose for each of the functions certain guidelines for translation.

In decoding, i.e., translating from English to Slovene one as a cardinal numeral or as the first element in the pair one-another, one-other in the analyzed texts is 
usually translated with the Slovene cardinal numeral en $-a-o$, eden. It is also observed that translators frequently leave out the numeral before body parts of animate beings. In encoding, i.e., translating from Slovene to English, the translators consistently used the numeral one as a translation of en, eden. The exceptions were certain Slovene correlative structures (e.g., od duri do duri 'from door to door'), which the translators translated by one-another and thus avoided repetition.

As a Slovene translation of the generic personal pronoun one the pronominal noun človek is usually found. In translations there are often units of translation with the impersonal verb form with se and metaphorical use of the second person singular. In encoding, the generic personal pronoun one in the original always corresponds to the pronominal noun človek.

One as a part of an indefinite pronoun is usually translated with the appropriate pronoun in Slovene. Thus no one is translated by the negative pronoun nihče or nobeden; any one by the pronouns kdo or kdorkoli; someone by the pronouns kdo or nekdo; and every one by the substantivized adjectival pronoun vsak $-a-o$. In translation from Slovene into English there was only one example of an indefinite pronoun one as an equivalent to nobeden in the original.

In the majority of examples where one stands as a nominal substitute for the head of a nominal phrase, Slovene employs a substantivized adjective, which is always in the definite form. Occasionally translators introduce a new noun, which indicates that the traditional advice to translators about using a substantivized Slovene adjective in this function for English one is not always valid. In encoding the translators used one in this function only four times: twice as a translation of a Slovene adjective, twice one was their paraphrase of the original.

One as a substitute for an indefinite nominal phrase is usually translated by Slovene pronouns; translations with a repeated noun as a substitute for one are also frequently enountered. Sometimes translators introduce a near synonym or paraphrase. In the translations from Slovene to English, one was not used in this function even once. Apparently translators are not very aware that the repetition of a noun, the introduction of a near synonym and the excessive use of pronouns are not such frequent stylistic devices in English texts as they are in Slovene; nor that in English texts in this function the word one is usually found.

One as a pro-noun, i.e., in the meaning 'person' or 'people', in Slovene becomes an emphasized personal pronoun, and translators frequently paraphrase it as such. In the translation into English one in this function corresponds to an emphasized demonstrative pronoun.

One as a pronoun of indefinite unity occurs only in encoding and always in the meaning neki $-a-o$ 'a certain one, some'.

Thus one in the function of a cardinal numeral, a generic person, an indefinite pronoun, a pro-noun, and a pronoun of indefinite unity do not cause particular problems for translators from English to Slovene. This is not true for one in the function of a nominal substitute, since in decoding a substantivized adjective cannot always be used as a translation. Besides this, it seems that translators translating from English to Slovene are relatively unaware of the frequency of the use of this cohesive element in English, as one in this function in translation is rarely encountered. 